\title{
Conventional Identification of Streptococcus uberis Isolated from Bovine Mastitis in Argentinean Dairy Herds
}

\author{
L. Odierno, ${ }^{\star 1}$ L. Calvinho,† P. Traverssa, ${ }^{\star}$ M. Lasagno, ${ }^{\star}$ C. Bogni, ${ }^{\star}$ and E. Reinoso* \\ *Departamento de Microbiología e Inmunología, Facultad de Ciencias Exactas, Físico-Químicas y Naturales, \\ Universidad Nacional de Río Cuarto, Ruta 36 Km 601, 5800 Río Cuarto, Córdoba, República Argentina \\ †Estación Experimental Agropecuaria Rafaela, Instituto Nacional de Tecnología Agropecuaria, \\ 2300 Rafaela, Santa Fe, República Argentina.
}

\begin{abstract}
The objective of this study was to evaluate a conventional scheme for identifying Streptococcus uberis strains isolated from bovine mastitis. Seventy-five gram-positive, catalase-negative cocci were collected from cows with mastitis from 19 dairy herds located in the east-central region of Argentina. Five American Type Culture Collection strains and bovine isolates were identified by the API 20 Strep system and by restriction fragment length polymorphism analysis of 16S rDNA. A conventional scheme based on 11 biochemical tests was selected for identification of Strep. uberis strains: the Christie-Atkins-Munch-Petersen reaction; hydrolysis of Arg, esculin, and sodium hippurate; growth in inulin, mannitol, raffinose, salicin, and sorbitol; and growth at $45^{\circ} \mathrm{C}$ and in $6.5 \% \mathrm{NaCl}$. Reference strains and 25 bovine isolates were classified accurately to the species level by the conventional scheme in a blind assay. Each reference strain and each bovine isolate were identified as belonging to the same species following these 3 methods. The remaining 50 isolates identified as Strep. uberis by the API 20 Strep system and 16S rDNA RFLP were assayed by the conventional scheme. This scheme correctly identified $47(94 \%)$ of 50 isolates as Strep. uberis by comparing their biochemical profile with that of the reference strain. Three (6\%) of the 50 isolates were classified as Strep. uberis by the API 20 Strep system and by 16S rDNA RFLP and were identified as Enterococcus faecalis by the conventional scheme. Thirty percent of the Strep. uberis strains showed biochemical profiles identical to the Strep. $u b$ eris American Type Culture Collection 27958 strain. Seventy percent of the Strep. uberis strains demonstrated variability compared with the reference strain, resulting in 19 different biochemical profiles. The conventional scheme proposed in this study resulted in a relatively low number of misidentifications and could
\end{abstract}

Received December 27, 2005.

Accepted May 26, 2006.

${ }^{1}$ Corresponding author: lodierno@exa.unrc.edu.ar biochemically identify not only typical, but also atypical Strep. uberis strains. This conventional scheme can be considered an adequate method for identifying Strep. uberis strains isolated from bovine mastitis because of its affordable cost in developing countries, and it may contribute to determining the frequency of isolation of Strep. uberis strains in Argentinean dairy herds.

Key words: Streptococcus uberis, bovine mastitis, conventional identification

\section{INTRODUCTION}

Bovine mastitis is the most costly disease among dairy cows. Estimates of losses caused by mastitis range from US $\$ 35$ to $\$ 295$ per cow per year (DeGraves and Fetrow, 1993). In Argentina milk production losses have been estimated at US\$221 million a year (Asociación Argentina de lucha contra la mastitis, 1983).

Streptococcus uberis is known worldwide as an environmental pathogen responsible for a high proportion of cases of clinical and subclinical mastitis in lactating cows and is also the predominant organism isolated from mammary glands during the nonlactating period (Bradley, 2002; Khan et al., 2003). Accurate and costeffective methods of identifying mastitis pathogens are important for the diagnosis, surveillance, and control of this economically important disease among dairy cows (McDonald, 1984; Leigh, 1999).

Gram-positive, catalase-negative, esculin-hydrolyzing cocci isolated from cases of clinical and subclinical mastitis are commonly categorized as Strep. uberis in routine diagnostic laboratories. The heavy workload of mastitis diagnostic services does not allow more accurate identification. Upon closer examination, however, many of these bacteria may in fact be very different from this major streptococcal pathogen. The differential scheme for mastitis streptococci and enterococci of the US National Mastitis Council (National Mastitis Council, 1990) lists Strep. uberis, Streptococcus bovis, Streptococcus equinus, Enterococcus faecalis, Enterococcus faecium, and Enterococcus saccharolyticus as esculinhydrolyzing species and Streptococcus dysgalactiae and 
Streptococcus equi as esculin-variable species. More recently, 2 new esculin-hydrolyzing streptococcal species, Streptococcus parauberis (Williams and Collins, 1990) and Streptococcus plurianimalium (Devriese et al., 1999), were isolated from bovine mastitis. However, according to different authors (King, 1981; Calvinho et al., 1991; Khan et al., 2003), Strep. uberis, Strep. dysgalactiae, Strep. bovis, Strep. equinus, and E. faecalis represent the esculin-positive or esculin-variable cocci most frequently isolated from mastitic cows. Farrow and Collins (1984) examined a collection of strains, most of which were nonhuman isolates, and reported that the phenotypically described Strep. bovis and Strep. equinus type strains belonged to a single DNA group and corresponded to the same species.

Identification of Strep. uberis is currently based on observation of the cultural and morphological characteristics, determination using biochemical tests, and enzyme activity (Leigh, 1999; Khan et al., 2003). On the other hand, several commercial microbial identification systems have also been used to differentiate Strep. $u b$ eris from the other streptococci and enterococci isolated from bovine mastitis (Watts, 1989; Freney et al., 1992), and more recently, molecular tools such as PCR-based protocols have been proposed to provide an accurate identification of Strep. uberis isolates (Hassan et al., 2001; Schlegel et al., 2003; Kawata et al., 2004). Among these, RFLP analysis of $16 \mathrm{~S}$ rDNA was proposed as a general method for bacterial identification and typing (Jayarao et al., 1992). Perhaps the greatest disadvantage of identification techniques based on commercial rapid systems and molecular tools is that these methods can be expensive for most laboratories that wish to offer analyses at an affordable cost. The objective of this study was to evaluate a conventional scheme based on 11 biochemical tests for identification of Strep. uberis strains collected from the mammary glands of cows with mastitis from 19 dairy herds located in the east-central region of Argentina.

\section{MATERIALS AND METHODS}

\section{Bacteria}

Five American Type Culture Collection (ATCC) strains, sent by M. Gottschalk and B. Jayarao, including Streptococcus agalactiae ATCC 27956, Strep. dysgalactiae ATCC 27957, Strep. uberis ATCC 27958, Strep. equinus ATCC 27960, and E. faecalis ATCC 19433, were used in this study. In addition, over a period of $12 \mathrm{mo}$, 75 bacterial cultures were collected and presumptively identified as streptococci or enterococci by colony appearance, gram stain reaction, and catalase test (Hogan et al., 1999). The collected isolates were obtained from mammary glands of cows with mastitis from 19 dairy herds located in the east-central region of Argentina. Four isolates per dairy herd were stored at $-20^{\circ} \mathrm{C}$ in Todd-Hewitt broth (Sigma-Aldrich Co., St. Louis, MO) with $20 \%$ glycerol. All ATCC strains and bovine isolates were subcultured from storage media onto 5\% sheep blood agar plates and were identified by the API 20 Strep system (bioMérieux, Inc., Durham, NC; Poutrel and Ryniewicz, 1984) and by 16S rDNA RFLP, as previously described (Jayarao et al., 1992).

\section{Biochemical Tests}

Eleven biochemical tests were selected for identification of Strep. uberis strains: the Christie-AtkinsMunch-Petersen (CAMP) reaction (Hogan et al., 1999); esculin hydrolysis (Hogan et al., 1999); sodium hippurate hydrolysis (Baron et al., 1994a); Arg hydrolysis (McDonald and McDonald, 1976); growth in inulin, mannitol, raffinose, salicin, and sorbitol (McDonald and McDonald, 1976); and growth at $45^{\circ} \mathrm{C}$ and in $6.5 \% \mathrm{NaCl}$ (Baron et al., 1994b). The Todd-Hewitt broth was used as a basal medium for temperature- and salt-tolerance tests. Five reference strains and 25 bovine isolates previously identified by the API 20 Strep system and by 16S rDNA RFLP, were classified to the species level by biochemical tests in a blind assay. Five representative colonies, obtained by streaking $5 \mu \mathrm{L}$ of Todd-Hewitt broth-glycerol onto $5 \%$ sheep blood agar plates, were picked from each plate and used in each biochemical test. The remaining 50 isolates of bovine origin, identified by the API 20 Strep system and by $16 \mathrm{~S}$ rDNA RFLP, were subjected to the biochemical tests, and the results were compared with biochemical profiles obtained from reference strains. Each isolate was identified to the species level when 8 of the 11 biochemical tests were identical to one of the reference strains and at least 2 were different from each of the other reference strains.

\section{RESULTS}

Reference strains were identified to the species level by the API 20 Strep system and by $16 \mathrm{~S}$ rDNA RFLP. Biochemical tests of reference strains were determined by using the conventional scheme proposed for Strep. uberis identification. Reference strains were classified accurately to the species level in a blind assay by comparing their biochemical profiles with previously reported results (McDonald and McDonald, 1976; Garvie and Bramley, 1979; Watts, 1988; Lämmler, 1991; Devriese et al., 1999; Facklam, 2002; National Mastitis Council, 2002; Fortin et al., 2003; Khan et al., 2003). Table 1 shows the identification of the reference strains by the conventional scheme obtained after each biochemical test was repeated 3 times for each isolate. 
Table 1. Identification of reference strains by the conventional scheme ${ }^{1}$

\begin{tabular}{|c|c|c|c|c|c|c|c|c|c|c|c|}
\hline \multirow[b]{2}{*}{ Reference strains } & \multirow{2}{*}{$\begin{array}{l}\text { CAMP } \\
\text { reaction }\end{array}$} & \multicolumn{3}{|c|}{ Hydrolysis of } & \multirow{2}{*}{$\begin{array}{l}\text { Growth } \\
\text { in } 6.5 \% \\
\mathrm{NaCl}\end{array}$} & \multirow{2}{*}{$\begin{array}{l}\text { Growth } \\
\text { at } 45^{\circ} \mathrm{C}\end{array}$} & \multicolumn{5}{|c|}{ Growth in } \\
\hline & & ARG & ESC & HIP & & & INU & MAN & RAF & SAL & SOR \\
\hline Streptococcus agalactiae ATCC 27956 & + & + & - & + & - & - & - & - & - & + & - \\
\hline Streptococcus uberis ATCC 27958 & - & + & + & + & - & - & + & + & - & + & + \\
\hline Streptococcus equinus ATCC 27960 & - & - & + & + & - & - & - & - & + & + & - \\
\hline Enterococcus faecalis ATCC 19433 & - & + & + & + & + & + & - & + & - & + & + \\
\hline
\end{tabular}

${ }^{1}$ CAMP = Christie-Atkins-Munch-Petersen; ARG = arginine; ESC = esculin; HIP = sodium hippurate; INU = inulin; MAN = mannitol; $\mathrm{RAF}=$ raffinose $; \mathrm{SAL}=$ salicin $; \mathrm{SOR}=$ sorbitol.

Twenty-five gram-positive, catalase-negative cocci isolated from the mammary glands of cows with mastitis were identified by the API 20 Strep system and by 16S rDNA RFLP as Strep. agalactiae $(\mathrm{n}=5)$, Strep. dysgalactiae $(\mathrm{n}=5)$, Strep. uberis $(\mathrm{n}=5)$, Strep. equinus $(\mathrm{n}=5)$, and $E$. faecalis $(\mathrm{n}=5)$. In the blind experiment, these strains were successfully classified to the species level by the conventional scheme. Reference strains and the 25 bovine isolates were identified as belonging to the same species by the 3 methods.

The remaining 50 isolates identified as Strep. uberis by the API 20 Strep system and 16S rDNA RFLP were assayed by the conventional scheme. This scheme, based on 11 biochemical tests, correctly identified 47 (94\%) of the 50 isolates as Strep. uberis by comparing their biochemical profiles with that of the reference strain. All Strep. uberis strains were negative for growth in 6.5\% NaCl. Most of them (81 to 98\%) were positive not only for growth in mannitol, salicin, and sorbitol, but also for hydrolysis of Arg, esculin, and sodium hippurate, and they were negative for the CAMP reaction and for growth at $45^{\circ} \mathrm{C}$ and in raffinose. However, only $64 \%$ of the Strep. uberis strains were positive for growth in inulin (Table 2).

Three (6\%) of the 50 isolates were classified as Strep. uberis by the API 20 Strep system and by $16 \mathrm{~S}$ rDNA RFLP but were identified as $E$. faecalis by the conventional scheme.

Fourteen (30\%) of the 47 Strep. uberis strains showed biochemical profiles identical to the Strep. uberis ATCC 27958 strain. These strains were positive for growth in inulin, mannitol, and sorbitol, and for hydrolysis of Arg, esculin, and sodium hippurate, whereas they were negative for the CAMP reaction and for growth at $45^{\circ} \mathrm{C}$ and in $6.5 \% \mathrm{NaCl}$ and raffinose. The remaining $33(70 \%)$ Strep. uberis strains showed some variability with respect to the Strep. uberis reference strain, resulting in 19 different biochemical profiles, designated $\mathrm{A}$ to $\mathrm{S}$ (Table 3).

\section{DISCUSSION}

Streptococcal mastitis causes tremendous economic loss in bovine milk production, and Strep. uberis has become one of the most important environmental etiological agents responsible for cases of clinical and subclinical mastitis in lactating and nonlactating cows.

In this study, we proposed an identification scheme for Strep. uberis based on 11 biochemical tests. We were able to determine the agreement between the conventional scheme proposed and 2 other methods, the API 20 Strep system and $16 \mathrm{~S}$ rDNA RFLP. This scheme correctly identified 47 (94\%) of 50 isolates as Strep. uberis by comparing their biochemical profiles with that of a reference strain. The results showed that 3 of the 50 bovine isolates identified as $E$. faecalis by the conventional scheme were in fact Strep. uberis by the API 20 Strep system and 16S rDNA RFLP. The most common mistake was to identify Strep. uberis strains as Enterococcus spp. (Watts, 1989; Fortin et al., 2003). The conventional scheme proposed in this study resulted in a relatively low number of misidentifications.

In this study, all the strains classified by the conventional scheme as Strep. uberis were negative for growth in $6.5 \% \mathrm{NaCl}$, which agrees with the results of McDonald and McDonald (1976), Watts (1988), and the Na-

Table 2. Biochemical tests of 47 Streptococcus uberis strains isolated from bovine mastitis

\begin{tabular}{llc}
\hline & Strep. uberis & \\
Biochemical test & ATCC 27958 & Percentage $^{1}$ \\
\hline CAMP $^{2}$ reaction & - & 81 \\
Arg $^{3}$ & + & 83 \\
Esculin $^{3}$ & + & 89 \\
Sodium hippurate $^{3}$ & + & 96 \\
$6.5 \% \mathrm{NaCl}^{4}$ & - & 100 \\
$45^{\circ} \mathrm{C}^{5}$ & - & 98 \\
Inulin $^{4}$ & + & 64 \\
Mannitol $^{4}$ & + & 98 \\
Raffinos $^{4}$ & - & 94 \\
Salicin $^{4}$ & + & 96 \\
Sorbitol $^{4}$ & + &
\end{tabular}

${ }^{1}$ Percentage of strains showing reactions in biochemical tests identical to those obtained for the reference strain Strep. uberis ATCC 27958.

${ }^{2} \mathrm{CAMP}=$ Christie-Atkins-Munch-Petersen.

${ }^{3}$ Hydrolysis of.

${ }^{4}$ Growth in.

${ }^{5}$ Growth at. 
Table 3. Atypical biochemical profiles of 33 Streptococcus uberis strains isolated from bovine mastitis

\begin{tabular}{|c|c|c|c|}
\hline Profile & $\begin{array}{l}\text { Biochemical } \\
\text { test }\end{array}$ & $\begin{array}{l}\text { Atypical } \\
\text { biochemical } \\
\text { profiles }\end{array}$ & $\begin{array}{l}\text { No. }(\%) \\
\text { of Strep. } \\
\text { uberis } \\
\text { strains }^{1}\end{array}$ \\
\hline $\mathrm{A}$ & Sorbitol $^{2}$ & - & 1/33 (3) \\
\hline B & Sodium hippurate ${ }^{3}$ & - & $2 / 33(6)$ \\
\hline $\mathrm{C}$ & Mannitol $^{2}$ & - & $1 / 33(3)$ \\
\hline $\mathrm{D}$ & Inulin $^{2}$ & - & $5 / 33(15)$ \\
\hline $\mathrm{E}$ & Esculin $^{3}$ & - & $4 / 33(12)$ \\
\hline $\mathrm{F}$ & CAMP reaction & + & $2 / 33(6)$ \\
\hline G & Growth at $45^{\circ} \mathrm{C}$ & + & $1 / 33(3)$ \\
\hline $\mathrm{H}$ & $\mathrm{Arg}^{3}$ & - & $2 / 33(6)$ \\
\hline I & Raffinose $^{2}$ & + & 1/33 (3) \\
\hline $\mathrm{J}$ & Salicin $^{2}$ & - & $1 / 33(3)$ \\
\hline $\mathrm{K}$ & $\begin{array}{l}\text { CAMP reaction } \\
\text { Inulin }^{2}\end{array}$ & $\begin{array}{l}+ \\
-\end{array}$ & $5 / 33(15)$ \\
\hline $\mathrm{L}$ & CAMP reaction & + & 1/33 (3) \\
\hline M & $\begin{array}{l}\text { Raffinose }^{2} \\
\text { Arg }^{3} \\
\text { Inullin }^{2}\end{array}$ & $\begin{array}{l}+ \\
-\end{array}$ & 1/33 (3) \\
\hline $\mathrm{N}$ & $\begin{array}{l}\text { Inulin } \\
\text { Inulin }^{2} \\
\text { Sorbitol }^{2}\end{array}$ & - & 1/33 (3) \\
\hline $\mathrm{O}$ & $\begin{array}{l}\text { Esculin } \\
\text { Inulin } \\
\text { Sorbitol }^{2}\end{array}$ & $\begin{array}{l}- \\
- \\
-\end{array}$ & 1/33 (3) \\
\hline $\mathrm{P}$ & $\begin{array}{l}\text { CAMP reaction } \\
\text { Arg }^{3} \\
\text { Inulin }^{2}\end{array}$ & $\begin{array}{l}+ \\
- \\
-\end{array}$ & 1/33 (3) \\
\hline $\mathrm{Q}$ & $\begin{array}{l}\text { Esculin }^{3} \\
\text { Inulin }^{2} \\
\text { Salicin }^{2}\end{array}$ & $\begin{array}{l}- \\
- \\
-\end{array}$ & 1/33 (3) \\
\hline $\mathrm{R}$ & $\begin{array}{l}\text { Esculin }^{3} \\
\text { Inulin }^{2} \\
\text { Raffinose }^{2}\end{array}$ & $\begin{array}{l}- \\
- \\
+\end{array}$ & $1 / 33(3)$ \\
\hline $\mathrm{S}$ & $\begin{array}{l}\text { Arg }^{3} \\
\text { Esculin }^{3} \\
\text { Inulin }^{2}\end{array}$ & $\begin{array}{l}- \\
- \\
-\end{array}$ & $1 / 33(3)$ \\
\hline
\end{tabular}

\footnotetext{
${ }^{1}$ Number and percentage of Strep. uberis strains with atypical biochemical profiles showing only the tests that differ from those obtained for the reference strain Strep. uberis ATCC 27958 [CAMP (Christie-Atkins-Munch-Petersen) reaction -, hydrolysis of Arg +, hydrolysis of esculin + , hydrolysis of sodium hippurate + , growth in $6.5 \% \mathrm{NaCl}-$, growth at $45^{\circ} \mathrm{C}-$, growth in inulin + , growth in mannitol + , growth in raffinose -, growth in salicin + , growth in sorbitol +].

${ }^{2}$ Growth in.

${ }^{3}$ Hydrolysis of.
}

tional Mastitis Council (2002). However, Fortin et al. (2003) reported that nearly $32 \%$ of the Strep. uberis strains in that study were positive for growth in $6.5 \%$ $\mathrm{NaCl}$.

Nine of the 47 (19\%) bovine isolates characterized as Strep. uberis were CAMP reaction-positive, although Strep. uberis reference strain ATCC 27958 was not. These findings were similar to those of McDonald and McDonald (1976) and Lämmler (1991), but differed from those reported by Watts (1988), the National Mastitis Council (2002), and Khan et al. (2003).

Growth in inulin, which has been recommended as a routine test for identification of Strep. uberis (Hogan et al., 1999; Fortin et al., 2003), was observed in only
$64 \%$ of the isolates classified as Strep. uberis in this study. This result agrees with the work of Khan et al. (2003), who reported that $92(69 \%)$ of 132 Strep. uberis strains were positive for growth in inulin. In contrast, Watts (1988) reported that $100 \%(\mathrm{n}=33)$ of Strep. uberis strains were negative for growth in inulin, whereas Lämmler (1991) and Devriese et al. (1999) found that 100 and $98 \%$, respectively, of Strep. uberis strains were positive for growth in inulin.

In addition, $83 \%$ of the isolates characterized as Strep. uberis were positive for hydrolysis of esculin, which agrees with the results of Lämmler (1991), who reported that $83 \%(\mathrm{n}=36)$ of Strep. uberis strains were positive for esculin hydrolysis. Other authors (Garvie and Bramley, 1979; Khan et al., 2003), however, have reported that all Strep. uberis strains evaluated were positive for hydrolysis of esculin.

The CAMP reaction, hydrolysis of esculin, and growth in inulin have been recognized as variable characteristics for Strep. uberis (Lämmler, 1991; Fortin et al., 2003; Khan et al., 2003) and can therefore be considered dubious for identification of Strep. uberis strains. However, Fortin et al. (2003) proposed a flow chart for the identification of catalase-negative, non- $\beta$-hemolytic, grampositive cocci isolated from milk samples. The authors suggested that the CAMP reaction, the leucine aminopeptidase test, hydrolysis of esculin and of sodium hippurate, and growth in inulin and in raffinose should be routinely done.

The results obtained in this study showed that the conventional scheme proposed could biochemically identify not only typical but also atypical Strep. uberis isolates. This conventional scheme may be considered an adequate method to identify Strep. uberis strains isolated from bovine mastitis because of its affordable cost in developing countries, and it may contribute to determining the frequency of isolation of the Strep. $u b$ eris strains in Argentinean dairy herds, especially in herd-monitoring when regular sampling from all animals is performed.

\section{ACKNOWLEDGMENTS}

We acknowledge J. Chaves and José A. Giraudo for providing some of the milk samples. Thanks are due to M. Gottschalk and B. Jayarao for kindly providing the bacterial reference strains. This research was supported by grants from Agencia Córdoba Ciencia de la Provincia de Córdoba and Secretaría de Ciencia y Técnica de la Universidad Nacional de Río Cuarto, Argentina. E. Reinoso holds a postdoctoral fellowship with the Consejo Nacional de Investigaciones Científicas y Técnicas (CONICET). 


\section{REFERENCES}

Asociación Argentina de lucha contra la mastitis. 1983. Estimación de las pérdidas en volumen de producción de leche provocadas por la mastitis bovina en la República Argentina. Comité Federal de Lechería. Arch. Lechería 6:73.

Baron, E. J., L. R. Peterson, and S. M. Finegold. 1994a. Conventional and rapid microbiological methods for identification of bacteria and fungi. Pages 106-108 in Bailey and Scott's Diagnostic Microbiology. 9th ed. Mosby, St. Louis, MO.

Baron, E. J., L. R. Peterson, and S. M. Finegold. 1994b. Streptococci and related genera. Pages 336-337 in Bailey and Scott's Diagnostic Microbiology. 9th ed. Mosby, St. Louis, MO.

Bradley, A. J. 2002. Bovine mastitis: An evolving disease. Vet. J. 164:116-128.

Calvinho, L. F., C. A. Vitulich, M. A. Zurbriggen, V. R. Canavesio, and H. D. Tarabla. 1991. Prevalencia de microorganismos patógenos de la ubre en rodeos lecheros de la cuenca santafecina. Therios 18:189-196.

DeGraves, F. J., and J. Fetrow. 1993. Economics of mastitis and mastitis control. Vet. Clin. North Am. Food Anim. Pract. 9:421-434.

Devriese, L. A., P. Vadamme, M. D. Collins, N. Alvarez, B. Pott, J. Hommez, P. Butaye, and F. Haesebrouck. 1999. Streptococcus pluranimalium sp. nov. from cattle and other animals. Int. Syst. Bacteriol. 49:1221-1226.

Facklam, R. 2002. What happened to the streptococci: Overview of taxonomic and nomenclature changes. Clin. Microbiol. Rev. 15:613-630.

Farrow, J. A. E., and M. D. Collins. 1984. Taxonomic studies on streptococci of serological groups C, G and L and possibly related taxa. Syst. Appl. Microbiol. 5:483-493.

Fortin, M., S. Messier, J. Paré, and R. Higgins. 2003. Identification of catalase-negative, non- $\beta$-hemolytic, Gram-positive cocci isolated from milk samples. J. Clin. Microbiol. 41:106-109.

Freney, J., S. Bland, J. Etienne, M. Desmonceaux, J. M. Boeufgras, and J. Fleurette. 1992. Description and evaluation of the semiautomated 4-hour rapid ID 32 Strep method for identification of streptococci and members of related genera. J. Clin. Microbiol. 30:2657-2661.

Garvie, E. I., and A. J. Bramley. 1979. Streptococcus uberis: An approach to its classification. J. Appl. Bacteriol. 46:295-304.

Hassan, A. A., I. U. Khan, A. Abdulmawjood, and C. Lämmler. 2001. Evaluation of PCR methods for rapid identification and differentiation of Streptococcus uberis and Streptococcus parauberis. J. Clin. Microbiol. 39:1618-1621.
Hogan, J. S., R. N. Gonzalez, R. J. Harmon, S. C. Nickerson, S. P. Oliver, J. W. Pankey, and K. L. Smith. 1999. Testing procedures. Page 207 in Laboratory Handbook on Bovine Mastitis. 1st ed. Nat. Mastitis Counc., Inc., Madison, WI.

Jayarao, B. M., J. J. E. Doré, and S. P. Oliver. 1992. Restriction fragment length polymorphism analysis of $16 \mathrm{~S}$ ribosomal DNA of Streptococcus and Enterococcus species of bovine origin. J. Clin. Microbiol. 30:2235-2240.

Khan, I. U., A. A. Hassan, A. Abdulmawjood, C. Lämmler, W. Wolter, and M. Zschöck. 2003. Identification and epidemiological characterization of Streptococcus uberis isolated from bovine mastitis using conventional methods. J. Vet. Sci. 4:213-223.

Kawata, K., T. Anzai, K. Senna, N. Kikuchi, A. Ezawa, and T. Takahashi. 2004. Simple and rapid PCR method for identification of streptoccocal species relevant to animal infections based on $23 \mathrm{~S}$ rDNA sequence. FEMS Microbiol. Lett. 237:57-64.

King, J. S. 1981. Streptococcus uberis: A review of its role as a causative organism of bovine mastitis I: Characteristics of the organism. Br. Vet. J. 137:36-52.

Lämmler, C. 1991. Biochemical and serological properties of Streptococcus uberis. J. Vet. Med. Ser. B. 38:737-742.

Leigh, J. A. 1999. Streptococcus uberis: A permanent barrier to the control of bovine mastitis. Vet. J. 157:225-238.

McDonald, J. S. 1984. Streptococcal and staphylococcal mastitis. Vet. Clin. North Am. 6:269-285.

McDonald, T. J., and J. S. McDonald. 1976. Streptococci isolated from bovine intramammary infections. Am. J. Vet. Res. 37:377-381.

National Mastitis Council. 1990. Microbiological procedures for the diagnosis of bovine udder infection. Page 10 in Procedures for the identification of specific groups or species of microorganisms that cause mastitis. Natl. Mastitis Counc., Inc., Arlington, VA.

National Mastitis Council. 2002. Laboratory handbook on bovine mastitis. Natl. Mastitis Counc., Madison, WI. htpp://www.nmconline.org Accessed Nov. 11, 2005.

Poutrel, B., and H. Z. Ryniewicz. 1984. Evaluation of the API 20 Strep system for species identification of streptococci isolated from bovine mastitis. J. Clin. Microbiol. 19:213-214.

Schlegel, L., F. Grimont, P. Grimont, and A. Bouvet. 2003. Identification of major streptoccocal species by rrn-amplified ribosomal DNA restriction analysis. J. Clin. Microbiol. 41:6567-6666.

Watts, J. L. 1988. Characterization and identification of streptococci isolated from mammary glands. J. Dairy Sci. 71:1616-1624.

Watts, J. L. 1989. Evaluation of the Minitek gram-positive set for identification of streptococci isolated from bovine mammary glands. J. Clin. Microbiol. 27:1008-1010.

Williams, A. M., and M. D. Collins. 1990. Molecular taxonomic studies on Streptococcus uberis types I and II. Description of Streptococcus parauberis sp. nov. J. Appl. Bacteriol. 68:485-490. 